\title{
Development of Paspalum accession plugs for turfgrass establishment
}

\author{
Stella Áurea Cristiane Gomes da Silva ${ }^{1}$ (D), João Carlos Cezar de Albuquerque Filho ${ }^{1}$ [D, Simone Santos Lira Silva ${ }^{1}$ (D), \\ Ana Cecília Ribeiro de Castro $^{2}$ (D), Vivian Loges $^{1}$ (D) \\ ${ }^{1}$ Universidade Federal Rural de Pernambuco, Departamento de Agronomia, Recife-PE, Brazil \\ ${ }^{2}$ Embrapa Agroindústria Tropical, Fortaleza-CE, Brazil
}

\begin{abstract}
The selection of a genotype for lawn use must consider the plant survival rate and its soil covering ability, which is directly influenced by the growth of stolons and rhizomes. This study aimed to evaluate the growth and development of Paspalum accession plugs for turfgrass establishment. Plugs of six prostrate growth accessions of Paspalum lepton (PL 01), P. notatum (from PN 01 to PN 06) and Zoysia japonica (ZJ 01), which was used as the control treatment, were planted adding up to 7 treatments. At 63 days after planting, the survival rate, the number of shoots, the expansion capacity, plant height and soil coverage rate were evaluated. Moreover, at 72 days after planting, fresh and dry leaf, root, rhizome and/or stolon biomass, as well as root length were evaluated. Plugs of PL 01 presented the highest values regarding the number of shoots, the expansion capacity, soil coverage and the development of the root system with the largest biomass production. PL 01 and PN 05 along with ZJ 01 presented a high soil coverage rate and all the $P$. notatum $(\mathrm{PN})$ accessions together with $\mathrm{ZJ} 01$ maintained a lower plant height, but with a length root system higher than the control treatment ZJ 01. The P. lepton (PL 01) and P. notatum (PN 05) accessions can be recommended for turfgrass establishment using plug propagation methods.
\end{abstract}

Keywords: Paspalum lepton, P. notatum, growth, expansion, grass

\section{Resumo}

Desenvolvimento de plugs de acessos de Paspalum para o estabelecimento de gramados

A seleção de um genótipo para uso como gramado deve considerar a taxa de sobrevivência da planta e a capacidade de cobertura do solo, que está diretamente influenciada pelo crescimento de estolões e rizomas. Este estudo objetivou avaliar o crescimento e desenvolvimento de plugs de acessos de Paspalum para o estabelecimento de gramados. Foram plantados plugs de seis acessos de crescimento prostrado de Paspalum lepton (PL 01), P. notatum (de PN 01 a PN 06) e Zoysia japonica (ZJ 01) como tratamento controle, totalizando de 7 tratamentos. Aos 63 dias após o plantio, foi avaliada a taxa de sobrevivência, número de perfilhos, expansão, altura da planta e taxa de cobertura do solo. Aos 72 dias após o plantio, foi avaliada a biomassa fresca e seca foliar, radicular, de rizoma e/ou estolão e comprimento radicular. Os plugs de PL 01 apresentaram bom crescimento com elevado número de perfilhos, capacidade de expansão, cobertura do solo e bom desenvolvimento do sistema radicular com grande produção de biomassa. PL 01 e PN 05, juntamente com ZJ 01 apresentaram elevada taxa de cobertura do solo e todos os acessos de P. notatum (PN) junto com ZJ 01 mantiveram menor porte da planta, porém com um comprimento do sistema radicular superior ao do tratamento controle ZP 01. Os acessos de P. lepton (PL 01) e P. notatum (PN 05) podem ser recomendados para o estabelecimento de gramado utilizando os métodos de propagação por plugs.

Palavras-chave: Paspalum lepton, P. notatum, crescimento, expansão, grama

\section{Introduction}

Turfgrass has been used by humans to enhance their environment for over 10 centuries (Dhanasekaran, 2018). Grass presents great ecological importance and it has been used to prevent erosion, since its roots, stolons and rhizomes intertwine to form a continuous ground cover, which acts to restore degraded soils (Maximino et al., 2017). Besides, its use in landscaping brings also some advantages such as beauty.

*Corresponding authors: stella.agron@yahoo.com.br; vivian.loges2@ufrpe.br 
The turfgrass industry is a millionaire sector in the world. In Brazil, this sector stands out for lawns are present in football and golf fields, gardens, road side, urban landscaping, industrial areas, and parks (Souza et al., 2016).

As an example of native grass, Castro et al. (2015a) state that Paspalum notatum Flüggé, commonly known as Bahiagrass, is the most widely cultivated native species of the genus Paspalum L. In Brazil, the species is very popular for urban areas and it has been used for many different purposes such as recreational and ornamental lawns in tropical conditions, in industrial complexes and on road side (Castro et al., 2015a; Souza et al., 2016; Silva et al., 2018). P. notatum is a species that presents an extensive and deep root system which makes it tolerant to drought (Castro et al., 2015b).

For a better understanding of its ecology, growth dynamics and potential use, it is necessary to know the propagation method that allows understanding its development mechanism. The vegetative propagation of $P$. notatum is the most used method to stablish turfgrass areas with the advantage of maintaining the plant parental characteristic, planting uniformity, faster establishment and lower weed development (Souza et al., 2016).

Depending on the species and cultivar, the adopted vegetative propagation may be done by plugging. Plugs are plant seedlings prepared for cultivation in soils from 6 to 12 centimeters deep. The closer seedlings are transplanted, faster the soil will be covered, but it requires much more seedlings, making planting more expensive. Planting of plugs may be mechanized or manually, in smaller cultivation areas (Polomski and McCarty, 2003).

Grasses with stoloniferous growth habit (aerial stems with nodes that develop roots when touch the ground) or rhizomatous growth habit (subterranean stems, aclorophyllous, usually large due the accumulation of reserves) could originate roots and new aerial shoots and plants (Marchi and Sallés, 2015).

However, the selection of a genotype for lawn-use has consider the survival of the propagating material and its ability to soil cover (Martello et al., 2014), which is directly influenced by the plant architecture, the position of its shoots and nutrient storage. In the Poaceae family, the type of branches, stolons and rhizomes, influence the growing direction of the stems in relation to the soil, which allows many species to adapt to different environments (Fabbri et al., 2019).

As the plant architecture and soil cover may vary between species or between genotypes of the same species, this study aimed to evaluate the growth and development of Paspalum accessions for turfgrass establishment through planting a single plug.

\section{Material and Methods}

The experiment was carried out from July to September 2017, under the following coordinates $8^{\circ} 01^{\prime} 06^{\prime \prime}$ South, $34^{\circ} 56^{\prime} 49^{\prime}$ ' West and $6 \mathrm{~m}$ of altitude. The region presents the As' weather (tropical hot humid with rainfall in fall to winter) according to the classification of Köppen (1948).

Six accessions of prostrate growth habit provided by the Germplasm Active Bank of Paspalum from Embrapa Pecuária Sudeste (São Carlos-SP, Brazil) were evaluated: Paspalum lepton (PL 01) and P. notatum (PN 01; PN 02; PN 03; PN 04 and PN 05). To serve as a control treatment, a commercial cultivar of Zoysia japonica grass (ZJ 01) was used, adding up to 7 treatments. The Zoysiagrass cv. Esmeralda (Zoysia japonica Steud.), a stoloniferous and rhizomatous species, is the most used species in Brazilian (Lima et al., 2018). The plug size was standardized around $10 \mathrm{~cm}$ (Figure 1) including the rhizomes or stolons and the aerial part.
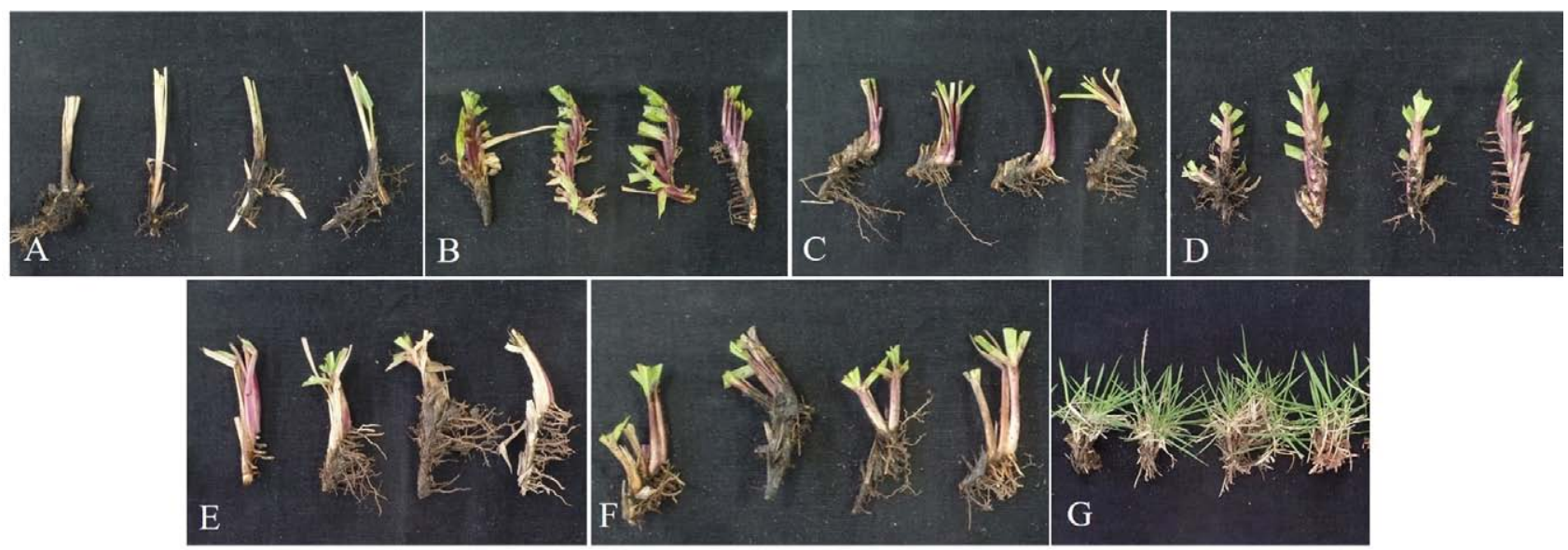

Figure 1. Plugs of Paspalum lepton (PL 01 - A), P. notatum (PN 01 - B; PN 02 - C; PN 03 - D; PN 04 - E; PN 05 - F) and control treatment Zoysia japonica $(\mathrm{ZJ} 01-\mathrm{G})$ standardized with approximate $10 \mathrm{~cm}$ to evaluated the growth and development for turfgrass establishment. 
The experiment was conducted in a protected environment $(21.0 \mathrm{~m}$ long, $7.0 \mathrm{~m}$ wide and $3.0 \mathrm{~m}$ high greenhouse), covered with a diffuse plastic of 120 microns and on the sides shading screens of $30 \%$. Plug planting was done in polyethylene trays $(27 \mathrm{~cm}$ width $\mathrm{x} 38 \mathrm{~cm}$ length x $6 \mathrm{~cm}$ depth) equivalent to an area of $1026 \mathrm{~cm}^{2}$, with commercial substrate (Figure 2A), and four repetitions.

The trays were placed on concrete benches $(4.80 \mathrm{~m}$ long, $1.4 \mathrm{~m}$ wide, $1.06 \mathrm{~m}$ high and $5 \%$ slope), arranged in 4 randomized blocks with 7 treatments ( 6 accessions of Paspalum spp. and the control treatment ZJ 01) (Figure 2B). Irrigation was performed by capillarity between 45 min intervals and an amount of $0.28 \mathrm{~L} . \mathrm{s}^{-1}$ every $15 \mathrm{~min}$ of irrigation was applied.

At 63 days after planting (DAP), the following variables were analyzed: survival rate (SR in \%); number of shoot (NS), measured in the rhizomes or stolons of each plant; lateral growth expansion $\left(\mathrm{E}\right.$ in $\left.\mathrm{cm}^{2}\right)$, obtained from the length of largest side of the plant $(\mathrm{cm})$ multiplied by the perpendicular length $(\mathrm{cm})$; height $(\mathrm{H}$ in $\mathrm{cm})$, obtained from substrate level up to the apex of the plant; and soil coverage rate (SCR in \%), obtained through image analysis.

The SCR analyzes were obtained through image analysis, captured by a 14.2-megapixel Samsung camera, 5 x Zoom lens $27 \mathrm{~mm}$ Wide Recording 280 x 720p. The images were then converted into Joint Photographic Experts Group format (JPEG) and processed by the Embrapa's SisCob software.

At 72 days after planting (Figure 2C), plants were fragmented in the laboratory, in order to separate the roots, leaves and rhizomes and/or stolons. The biomass and root length analysis required more handling, both in cleaning the plant material in order to avoid the loss of the vegetative parts; as well as in the evaluation of the variables. For it is an analysis that requires precision, predisposing an entire day for the analysis each block.
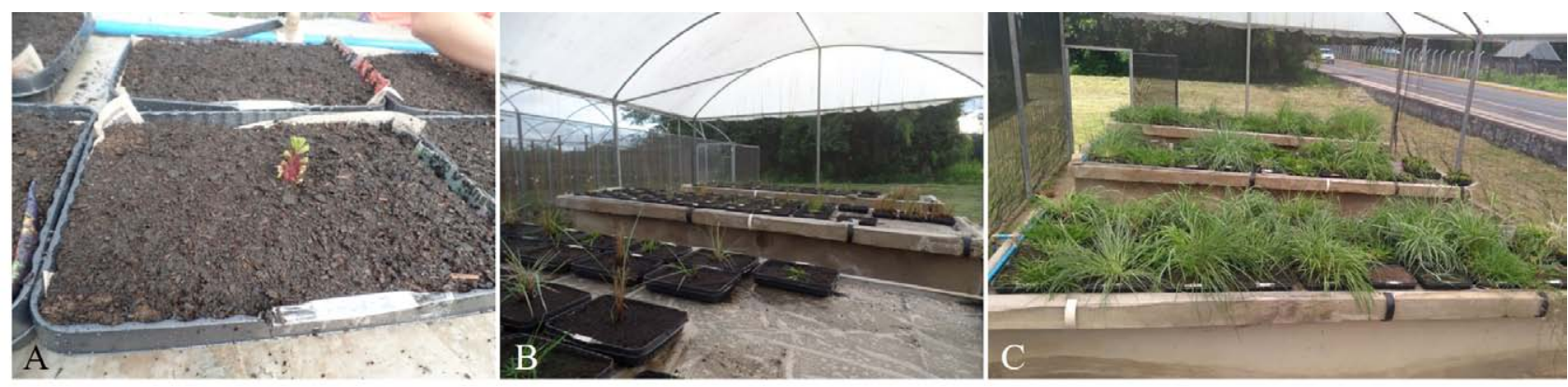

Figure 2. Evaluation of Paspalum accessions propagated by plugs for turfgrass establishment: one plug per tray with commercial substrate (A); trays 21 days after planting placed on concrete benches with irrigation by capillarity (B); and experiment 72 days after planting (C).

The parts were weighed to obtain the following variables: fresh leaf biomass (FLB in g); dry leaf biomass (DLB in g); fresh root biomass (FRB in g); dry root biomass (DRB in g); fresh biomass of rhizome and/or stolon (FRSB in g); dry biomass of rhizome and/or stolon (DBRS in g); and root length (RL in $\mathrm{cm}$ ). The dry mass was obtained by drying the plant parts at $65^{\circ} \mathrm{C}$ per 72 hours in a forced aeration oven, until obtaining constant weight (Haydock and Shaw, 1975).

The analysis at 63 and 72 DAP occurred in the plugs/ plants per accession (in all four replications). A randomizedin-block experimental design was used, and the treatments means were compared by the Scott Knott test and the Simple Person Correlation (test $t$ ) at $1 \%$ and $5 \%$ probability level, respectively, by the statistical software GENES (Cruz, 2013).

\section{Results and Discussion}

Differences were observed for the variables evaluated regarding growth and plant development, which allow the selection of Paspalum accessions for turfgrass establishment using the plug propagation methods.
At 63 days after planting, it was found a survival rate (SR) of $100 \%$ in the plugs for all accessions (data not tabulated). The plug ability to survive reduces the necessity of replanting and it also improves soil coverage. In an area with sandy soil, high temperatures and low precipitations, Castro et al. (2015a) found $100 \%$ of survival rates for PN 01, PN 02, PN 03, PN 04 and PN 05 accessions, using vegetative propagation methods such as plugs (a piece of sod with roots and soil). It is also essential for their establishment after the process of commercialization and period of transportation (Martello et al., 2014).

The PL 01 accession showed the highest number of shoots (29.50) among the evaluated Paspalum accessions, but it was inferior to the control treatment ZJ 01 (40.81) (Figure 3A). The PL 01 accession, with a rhizomatous and stoloniferous growth habit, showed the greatest lateral growth expansion $\left(8500.13 \mathrm{~cm}^{2}\right)$, which was higher than the observed in ZJ $01\left(4143.88 \mathrm{~cm}^{2}\right)$ (Figure 3B and Table 1). Kojoroski-Silva et al. (2011) emphasizes that longer stolon length in the meristematic nodes emitted shoots at longer distances and had greater capacity of mobility and colonization of new areas compared to shorter stolon length; which was observed in the PL 01 accession. 


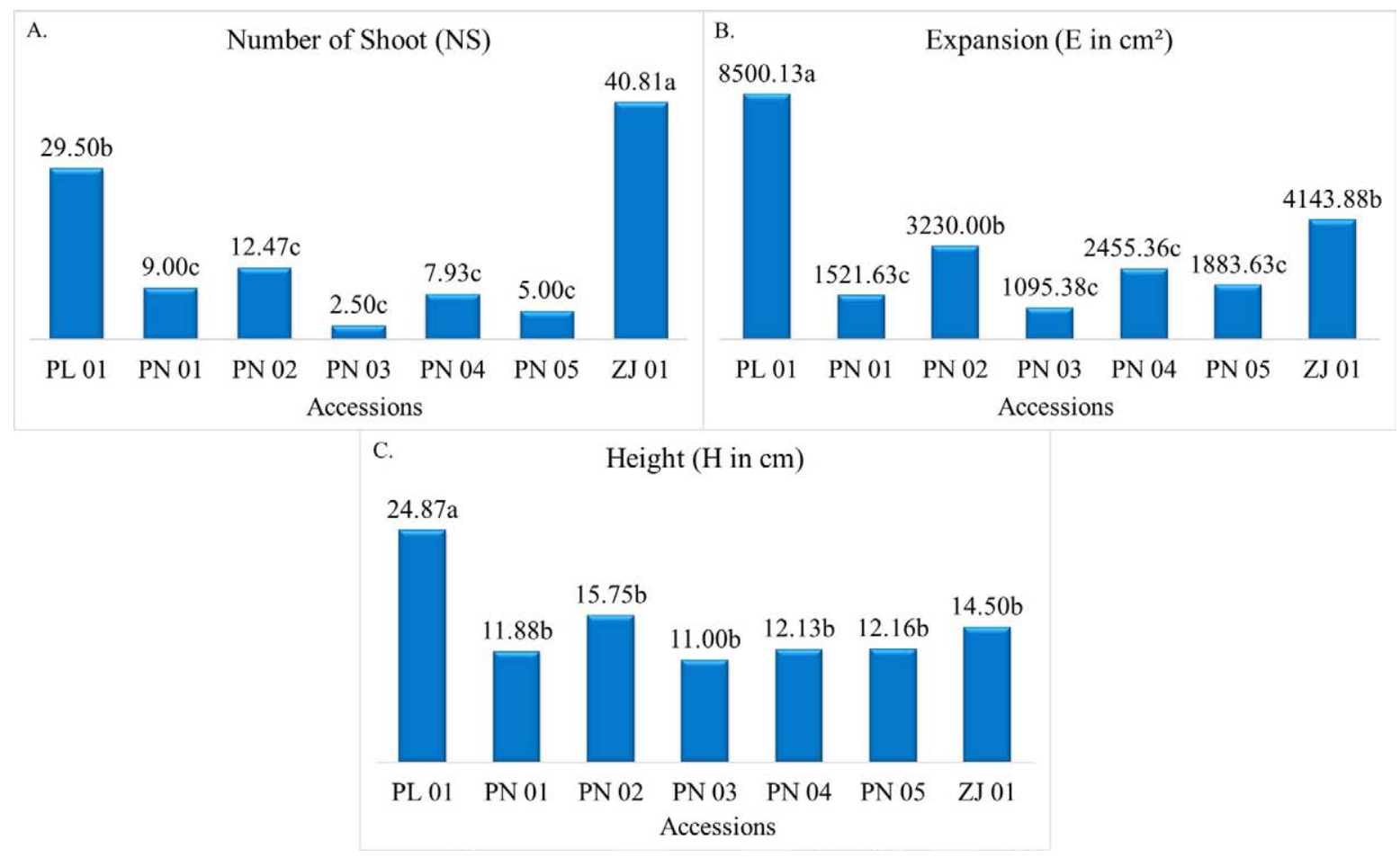

Figure 3. Number of shoots (A), expansion (B) and height (C) of Paspalum lepton (PL 01), P. notatum (PN 01 to PN $05)$ and control treatment Zoysia japonica (ZJ 01) at 63 days after planting. Averages followed by the same lowercase letter, do not differ significantly by the Scott-Knott test at $5 \%$ probability.

Table 1. Expansion (E) and height (H) of Paspalum lepton (PL 01), P. notatum (PN 01 to PN 05) and control treatment Zoysia japonica (ZJ 01) plants at 63 days after planting one plug per tray.

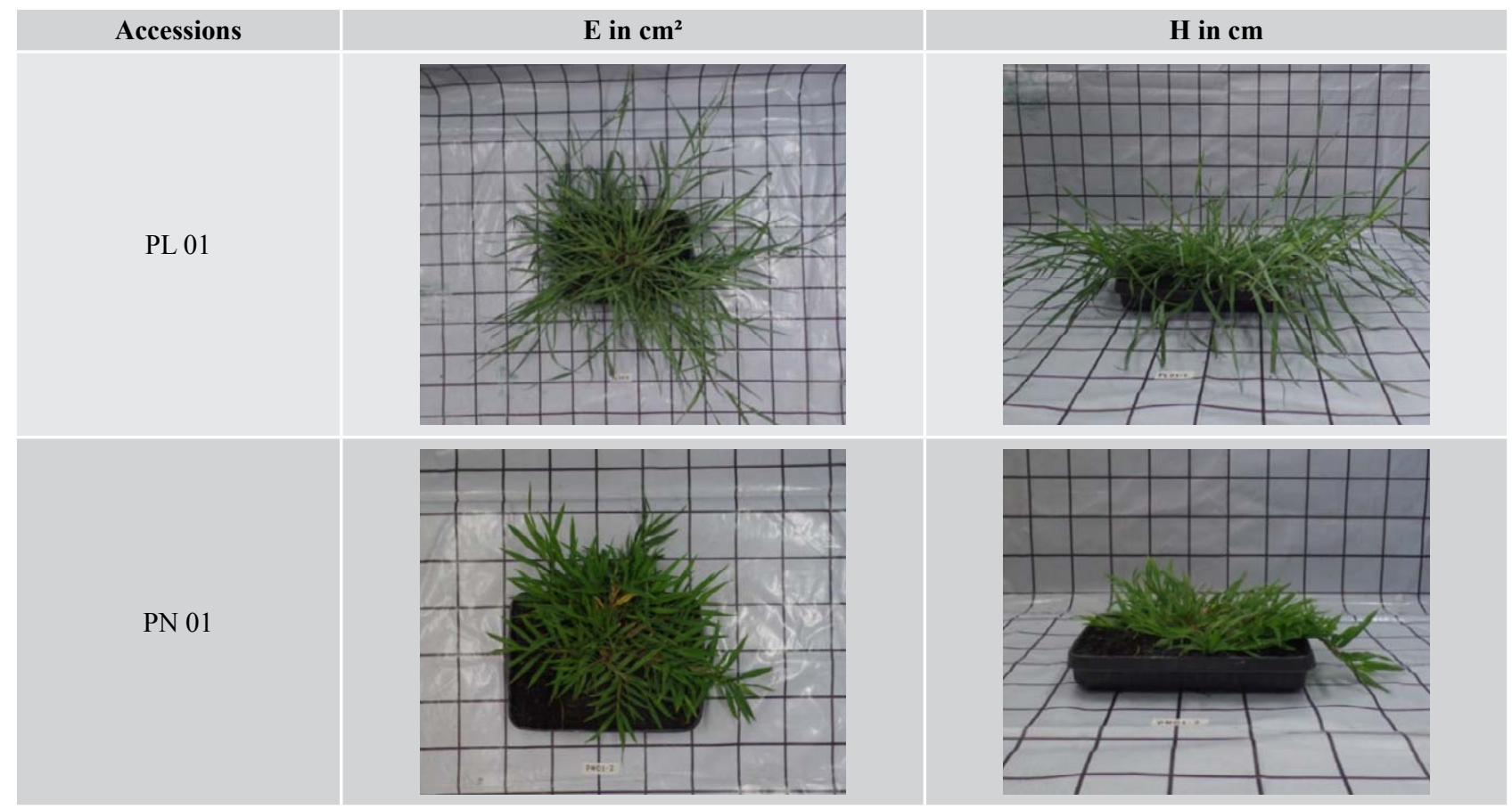


Table 1. cont.

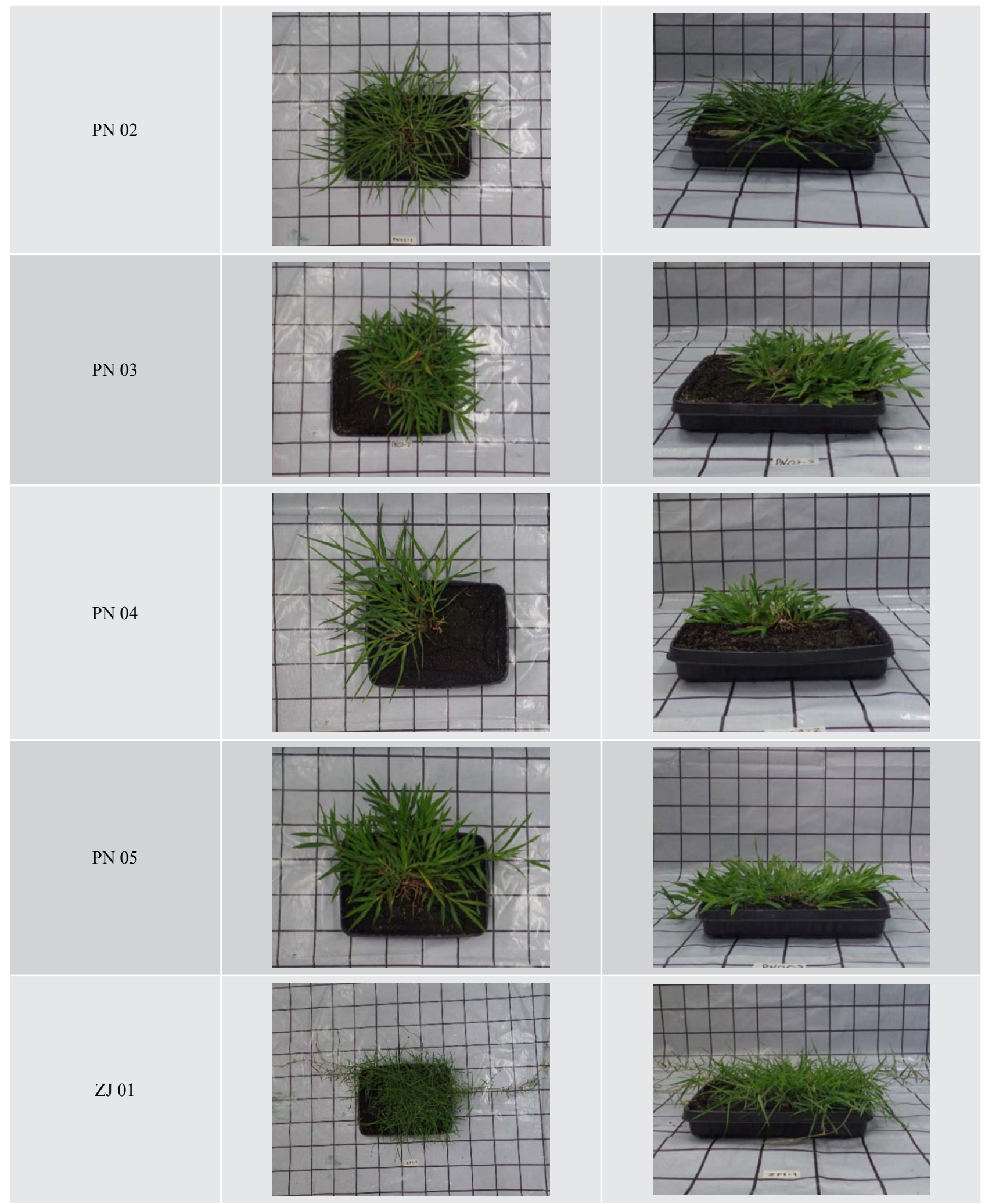

* Each square in the image is $10 \mathrm{~cm}$ on a side.

Pearson's positive correlation coefficients (r) observed between number of shoot (NS) and lateral growth expansion $(\mathrm{E})\left(\mathrm{r}=0.877^{*}\right)$ for the accessions of Paspalum, indicated that the greater the number of shoots, the greater the capacity of accession expansion
(Table 2). In fact, rhizomes or stolons, when emitting shoots, cause lateral growth and the occupation of available soil surfaces (Youngman et al., 2017) and it may favor the recovery of areas damaged by trampling, insects and diseases (Polomski and McCarty, 2003). The 
varieties of turf, that present rhizomatous growth, have a great capacity of regeneration, especially regarding the injuries caused by excessive traffic. It is caused due to the rhizome's location under the ground surface, being protected from direct mechanical damage (Martello et al., 2014).

Table 2. Pearson's correlation between the variables evaluated on Paspalum lepton (PL 01) and P. notatum (PN 01 to PN 05).

\begin{tabular}{|c|c|c|c|c|c|c|c|c|c|c|}
\hline Variables & $\mathbf{E}$ & $\mathbf{H}$ & SCR & FLB & DLB & FRB & DRB & FBRS & DBRS & RL \\
\hline $\begin{array}{l}\text { Number } \\
\text { of shoot } \\
\text { (NS) }\end{array}$ & $* 0.877$ & $* 0.768$ & 0.598 & $* 0.831$ & $* 0.831$ & $* * 0.916$ & $* * 0.922$ & $* 0.739$ & $* 0.790$ & 0.130 \\
\hline \multicolumn{2}{|c|}{ Expansion $\left(\mathrm{E}\right.$ in $\left.\mathrm{cm}^{2}\right)$} & $* * 0.918$ & 0.588 & $* * 0.909$ & *0.892 & $* 0.787$ & $* 0.783$ & $* 0.897$ & $* 0.769$ & 0.081 \\
\hline \multicolumn{2}{|c|}{ Height $(\mathrm{H}$ in $\mathrm{cm})$} & & 0.585 & $* 0.850$ & $* 0.839$ & 0.651 & 0.671 & $* 0.848$ & 0.633 & 0.201 \\
\hline \multicolumn{2}{|c|}{$\begin{array}{l}\text { Soil Coverage Rate } \\
\text { (SCR in } \%)\end{array}$} & & & 0.642 & 0.677 & 0.571 & 0.542 & 0.622 & 0.464 & 0.141 \\
\hline \multicolumn{2}{|c|}{$\begin{array}{l}\text { Fresh leaf biomass } \\
\qquad \text { (FLB in } \mathrm{g})\end{array}$} & & & & $* * 0.990$ & $* 0.825$ & $* 0.804$ & $* * 0.975$ & $* 0.784$ & 0.090 \\
\hline \multicolumn{2}{|c|}{$\begin{array}{l}\text { Dry leaf biomass } \\
\text { (DLB in } \mathrm{g} \text { ) }\end{array}$} & & & & & $* 0.849$ & $* 0.829$ & $* * 0.959$ & $* 0.762$ & 0.150 \\
\hline \multicolumn{2}{|c|}{$\begin{array}{l}\text { Fresh root biomass } \\
\qquad(\text { FRB in } \mathrm{g})\end{array}$} & & & & & & $* * 0.990$ & $* 0.722$ & $* 0.812$ & 0.202 \\
\hline \multicolumn{2}{|c|}{$\begin{array}{l}\text { Dry root biomass } \\
\text { (DRB in } \mathrm{g})\end{array}$} & & & & & & & 0.697 & $* 0.765$ & 0.218 \\
\hline \multicolumn{2}{|c|}{$\begin{array}{l}\text { Fresh biomass of } \\
\text { rhizome and/or stolon } \\
\text { (FBRS in } \mathrm{g} \text { ) }\end{array}$} & & & & & & & & $* 0.707$ & 0.090 \\
\hline \multicolumn{2}{|c|}{$\begin{array}{c}\text { Dry biomass of } \\
\text { rhizome and/or stolon } \\
\text { (DBRS in g) }\end{array}$} & & & & & & & & & 0.215 \\
\hline \multicolumn{2}{|c|}{$\begin{array}{l}\text { Root length } \\
(\mathrm{RL} \text { in } \mathrm{cm})\end{array}$} & & & & & & & & & - \\
\hline
\end{tabular}

** and * referent to significant at $1 \%$ and $5 \%$ probability by the $t$ test.

The PL 01 accession also presented greater height $(\mathrm{H}$ equal to $24.87 \mathrm{~cm}$ ) when compared to the PN 01, PN 02, PN 03, PN 04, PN 05 and ZJ 01 group (11.00 to $14.50 \mathrm{~cm}$ ) (Figure $3 \mathrm{C})$. Turfgrass species with reduced height are more suitable for lawn maintenance, as they require lower costs regarding labor, fuel and equipment used to frequent mowing. Silva et al. (2018) performed 13 to 14 mowing, respectively, during the cultivation of PL 01 and PN 02 accessions under tropical conditions (Pernambuco Forest Zone, Brazil) from 63 to 187 DAP, for they exceeded a height of $7.5 \mathrm{~cm}$, suggested as ideal the height for lawns.

The PL 01 and PN 05 accessions presented higher soil coverage rates (SCR equal to $73.04 \%$ and $61.01 \%$, respectively) forming a single group along with the control treatment ZJ 01 (65.25\%). The other accessions presented soil coverage rates below $59.82 \%$ (Table 3 ). According to Souza et al. (2016), characteristics such as ground coverage, height and density, have a high degree of relevance for grasses used for turfgrass establishment, including ornamental use in domestic gardens and on green roofs.

The largest fresh and dry leaf; root and rhizome and/ or stolon biomass were observed in P. lepton accession (PL 01). The accession obtained fresh leaf biomass (FLB) equal to $109.12 \mathrm{~g}$, dry leaf biomass (DLB) of $18.10 \mathrm{~g}$, and fresh and dry root biomass (FRB and DRB), were 194.04 $\mathrm{g}$ and $43.49 \mathrm{~g}$, respectively. To the fresh and dry biomass of rhizome and/or stolon, was observed $306.78 \mathrm{~g}$ and 49.67 g, respectively. It has been seen that the accession showed higher accumulation of biomass in the root system, in rhizomes and stolons (Figure 4A-F).

According to the data, there is a significant positive correlation between FRB and DRB with the variables FLB $(\mathrm{r}$ $=0.825^{*}$; and $\mathrm{r}=0.804^{*}$, respectively $)$ and $\operatorname{DLB}\left(\mathrm{r}=0.849^{*}\right.$; and $\mathrm{r}=0.829^{*}$, respectively) (Table 2 ). 


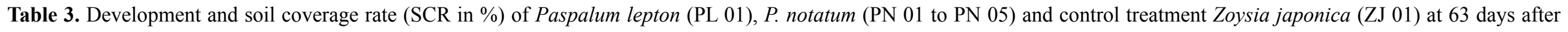
planting (DAP) one plug per tray.

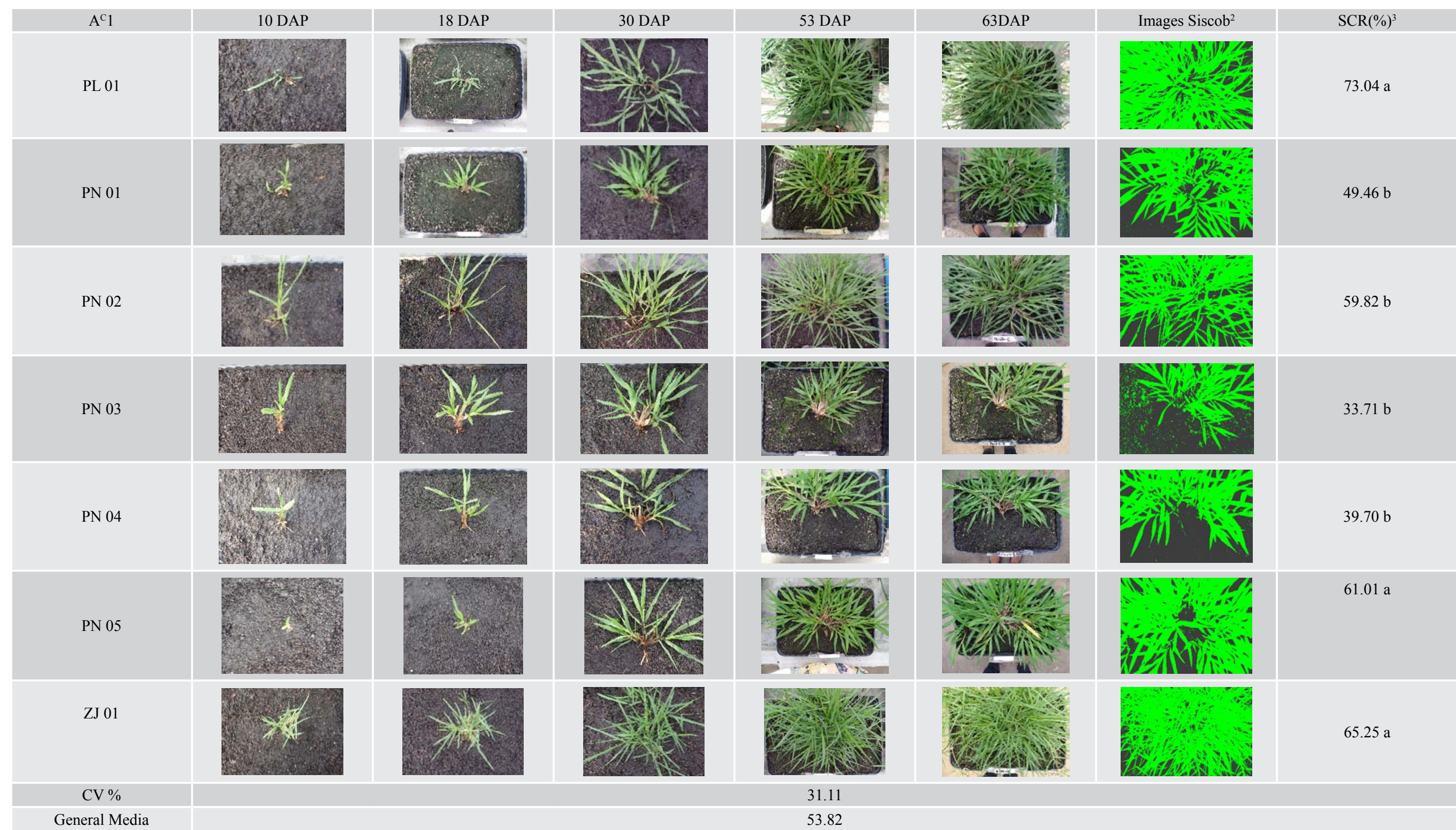

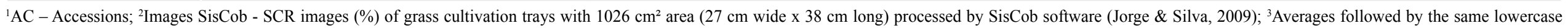
letter in the column, do not differ significant by the Scott-Knott test at $5 \%$ probability. 


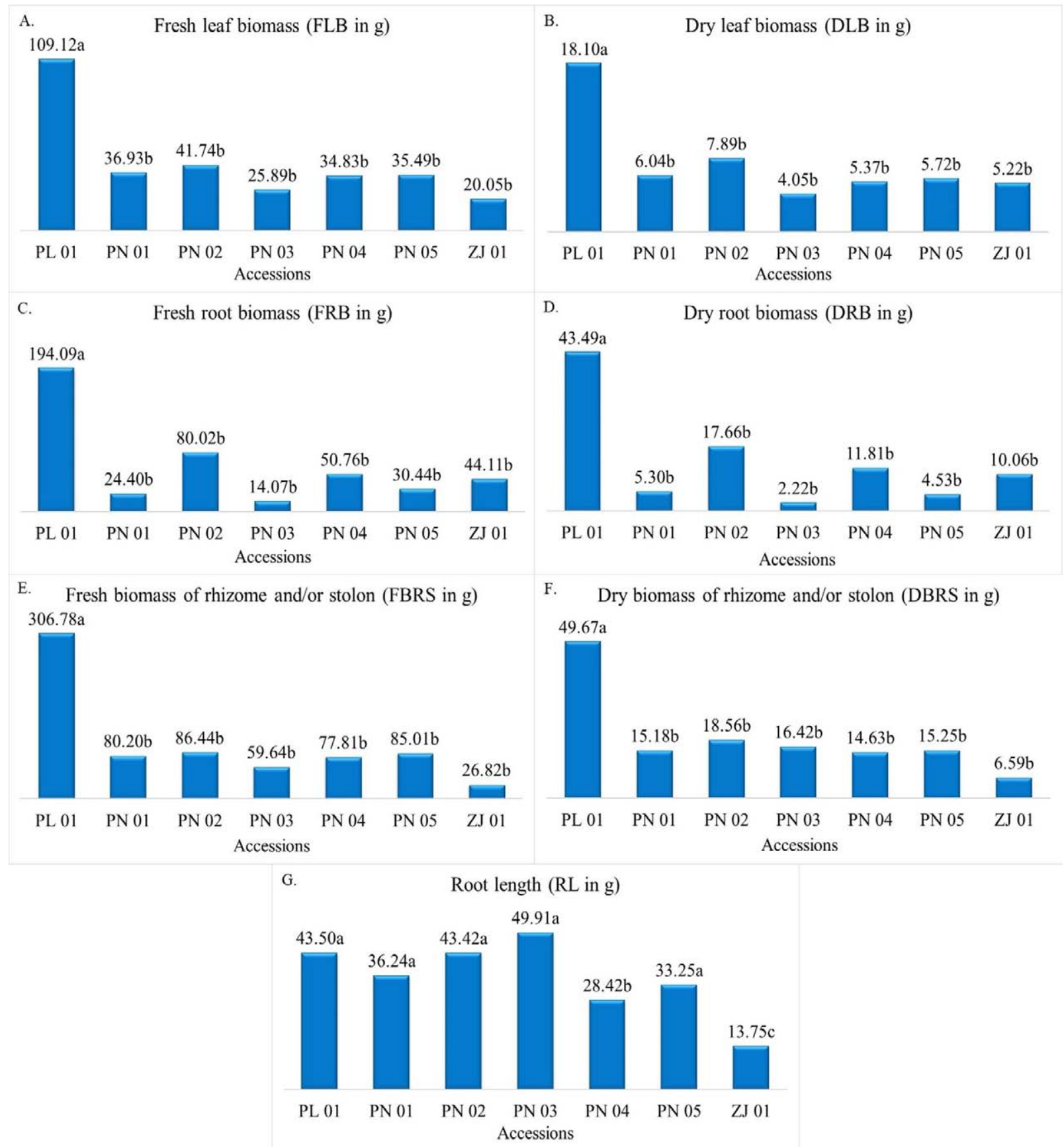

Figure 4. Fresh and dry leaf biomass ( $\mathrm{A}$ and $\mathrm{B})$, fresh and dry root biomass (C and D), fresh and dry biomass of rhizome and/or stolon (E and F) and root length (G) of Paspalum lepton (PL 01), P. notatum (PN 01 to PN 05) and control treatment Zoysia japonica (ZJ 01) at 72 days after planting. Averages followed by the same lowercase letter in the column, do not differ significantly by the Scott-Knott test at $5 \%$ probability. 
The other accessions were grouped into smaller biomass groups, for they were found to be similar to the control treatment Zoysia japonica (ZJ 01) (Figure 4A-F). These values demonstrate a high leaf and root density for PL 01, which is desirable for soil surface coverage, for it can contribute with benefits such as protective covering soil.

In the stage of establishment, the lawn covering speed determines the density of the surface cover (Souza et al., 2016), which in turn is associated with the production of biomass. Dense lawns are especially desired for landscaping, recreational and sporting purposes. High density is required not only to cover the terrain of sport lawns, but also to form a cushioning surface, which has the potential to reduce the impact of athletes' sports activities (Gobilik et al., 2013). Density, uniformity, texture, smoothness, soil coverage and bonding are functional characteristics and aesthetic value to be analyzed for the evaluation of the quality of a turfgrass by researchers and breeders (Glab et al., 2020).

This density is associate to the expansion of the lateral growth of the turf (E), which provides a positive correlation to the soil coverage rate $(\mathrm{SCR} ; \mathrm{r}=0.588)$ and significant correlations to FLB $\left(r=0.909^{* *}\right)$, DLB $(r=$ $0.892 *)$, FRB $(r=0.787 *)$, DRB $(r=0.783 *)$, FBRS $(r=$ $\left.0.897^{*}\right)$ and DBRS $\left(r=0.769^{*}\right)$. It shows that when lateral growth increases, it implies the production of leaf and root biomass, biomass of rhizomes and stolons (Table 2).

Regarding to root length (RL), the accessions PL 01, PN 01, PN 02, PN 03 and PN 05 showed similar performance, which was superior to PL 04 and also to the control treatment ZJ 01 (Figure 4G). For efficient soil coverage, the roots, along with rhizomes or stolons, help to sustain and cover the soil, reducing not only the direct environmental impacts on the soil, but also favoring the absorption of nutrients and water, which are essential elements for plant survival.

In an experiment evaluating the rate of establishment of Zoysia spp. and hybrids by sprigs, it has been demonstrated that the expansion of soil coverage is associated with the stolons growth rate. However, the number of stolons and rhizome branching yielded different colonizing capabilities of the entries. Such turfs have the ability to produce longer and thicker horizontal stems while others to produce higher density (Magni et al., 2017). In addition, it is believed that the potential root development and characteristics of the lawn profile provide important information about its drought resistance mechanisms and the development of drought resistant cultivars (Fuentealba et al., 2015).

The PL 01 accession showed a larger number of shoots and expansion capacity, greater biomass of the aerial part, root system and rhizome and stolon, which was superior to the control treatment ZP 01. The PL 01 and PN 05 presented highest rates of soil coverage, prostrate growth and good shoots development, which are desirable for the rapid turfgrass establishment and demonstrated the potential use of those accessions for several functionalities, including permanent protective soil coverage (Souza et al., 2016).

\section{Conclusions}

The accessions of P. lepton (PL 01) and P. notatum (PN 05) may be recommended for the establishment of lawns, using the plug propagation method, due to the good growth and development demonstrated by the high rates of shoots, as well as expansion and covering capacity, and accumulation of leaf, root, rhizomes and stolon biomass and root length.

\section{Acknowledgement}

To the UFRPE (Federal Rural University of Pernambuco) for the space used for the experiment, to the LAFLOR (Floriculture Laboratory of the Federal Rural University of Pernambuco) for the team work, to the support of the Higher Education Personnel Improvement Coordination (CAPES) - Brazil, to the Sandwich Doctorate Program Abroad (PDSE) - process 88881.133955/201601, and to the Brazilian Agricultural Research Corporation (EMBRAPA) for the granting of accessions of turfgrasses used in this experiment.

\section{Author Contribution}

S.Á.C.G.S.: Original draft preparation; development of the methodology; installation and conducting of the experiment in the field; character analysis; data and statistical analysis, data interpretation and creation of graphs and tables; and final article preparation (including substantive translation). J.C.C.A.F.: Statistical analysis of the original data; data entry, spreadsheet organization, scrub data and maintain research data for statistical analysis. S.S.L.S.: development of the methodology; character analysis, creation of an experimental design; and installation of the experiment in the field; article review. C.E.F.C.: Article review, specifically critical and correction, including pre stages for publications. V.L.: synthesis of the research idea, formulation of research goals and aims; development of the methodology; character analysis; creation of the experimental design; installation of the experiment in the field; article review, specifically critical and correction, including pre stages for publications. 


\section{References}

CASTRO, A.C.R.; TANIGUCHI, C.A.K.; SOUZA, F.H.D.; SILVA, T.F.; CAFÉ, F.B.S.; ARAGÃO, F.A.S.; LOGES, V. Evaluation of native Brazilian Paspalum germplasm as lawn for landscaping purpose. Acta Horticulturae, v.1104, p.505-510, 2015a. DOI: http://dx.doi.org/10.17660/ ActaHortic.2015.1104.73.05

CASTRO, A.C.R.; TANIGUCHI, C.A.K.; SOUZA, F. H. D.; ARAGÃO, F.A.S.; LOGES, V.; SILVA, T.F.; CAFÉ, F.B.S.; SILVA, E.B. Characterization of Paspalum accessions as ornamental lawn. Acta Horticulturae, v.1087, p.255-260, 2015b. DOI: http://dx.doi.org/10.17660/ ActaHortic.2015.1087.32

CRUZ, C.D. GENES - a software package for analysis in experimental statistics and quantitative genetics. Acta Scientiarum, v.35, n.3, p.271-276, 2013. DOI: http:// dx.doi.org/10.4025/actasciagron.v35i3.21251

DHANASEKARAN, D. Effect of sprigging density and foliar nitrogen on the growth of Bermuda grass (Cynodon dactylon L. Pers. x Cynodon transvaalensis). Journal of Horticultural Sciences, v.13, n.2, p.172-177, 2018. DOI: https://jhs.iihr.res.in/index.php/jhs/article/view/479

FABBRI, L.T.; INSAUSTI, P.; BATISTA, W.B.; RUA, G.H. Growth dynamics of the branching system in grasses: an architecture-based methodology for quantitative evaluation applied to two genotypes of Paspalum vaginatum. Rodriguésia, v.70, p.1-10, 2019. DOI: http:// dx.doi.org/10.1590/2175-7860201970081

FUENTEALBA, M.P.; ZHANG, J.; KENWORTHY, K.E.; ERICKSON, J.E.; KRUSE, J.; TRENHOLM, L.E. Root development and profile characteristics of Bermudagrass and Zoysiagrass. HortScience, v.50, n.10, p.1429-1434, 2015. DOI: https://doi.org/10.21273/HORTSCI.50.10.1429

GLAB, T.; SZEWCZYK, W.; GONDEK, K.; KNAGA, J.; TOMASIK, M.; KOWALIK, K. Effect of plant growth regulators on visual quality of turfgrass. Scientia Horticulturae, v.267, p.1-10, 2020. DOI: https://doi. org/10.1016/j.scienta.2020.109314

GOBILIK, J.; JEROME, V.; DAVID, V. Preliminary selection of some ecotypes of Cynodon dactylon (L.) Pers. in Sabah, Malaysia, for turfgrass use. Journal of Tropical Biology and Conservation, n.10, p.51-66, 2013.
HAYDOCK, K.P.; SHAW, N.H. The comparative yield method for estimating dry matter yield of pasture. Australian Journal of Experimental Agriculture and Animal Husbandry, v.15, n.76, p.663-670, 1975.

KOJOROSKI-SILVA, C.M.; SCHEFFER-BASSO, S.M.; CARNEIRO, C.M.; GUARIENTI, M. Desenvolvimento Morfológico das gramas Esmeralda, São Carlos e Tifton 419. Ciência e Agrotecnologia, v.35, n.3, p.471477, 2011. DOI: http://dx.doi.org/10.1590/S141370542011000300005

KÖPPEN, W.P. Climatologia: con un estudio de los climas de la tierra. México: Fondo de Cultura Económica, 1948. 479p.

LIMA, C.P.; BACKES, C.; SANTOS, A.J.M.; VILLAS BÔAS，R.L.; FERNANDES，D.M.; GODOY，L.J.G.; OLIVEIRA, M.R. Sod production and the effects of liquid organo-mineral fertilizers and thickness of sod. Scientia Agricola, v.75, n.4, p.346-353, 2018. DOI: http://dx.doi. org/10.1590/1678-992X-2016-0320

MAGNI, S.; POMPEIANO, A.; GAETANI, M.; CATUREGLI, L.; GROSSI, N.; MINELLI, A.; VOLTERRANI, M. Zoysiagrass (Zoysia spp. Willd.) for European lawns: A review. Italian Journal of Agronomy, v.12:925, p.395-402, 2017. DOI: http://dx.doi.org/10.4081/ ija.2017.925

MARCHI, M.M.; SALLÉS, J.M. Quem são as gramíneas? In: MARCHI, M.M.; BARBIERI, R.L. (eds.). Cores e formas do bioma pampa: gramíneas ornamentais nativas. Brasília, DF: Embrapa, p.24-30, 2015.

MARTELLO, J.M.; CASTILHO, R.M.M.; PAGLIARINI, M.K. Pós-colheita de tapetes de grama esmeralda em relação aos níveis de empilhamento e ambiente de armazenamento. Tecnologia e Ciência Agropecuárea, v.8, n.1, p.61-66, 2014.

MAXIMINO, J.V.O.; MACHADO, M.A.S.; MITTELMANN, A.; PINHEIRO, E.C.; PIRES, E.S.; LONGARAY, M.B.; SOUZA, F.H.D.; STUMPF, E.R.T. Potencial de produção de sementes de gramíneas para a implantação em gramados. Ornamental Horticulture, v.23, p.200-206, 2017. DOI: http://dx.doi.org/10.14295/ oh.v23i2.1011 
POLOMSKI, B.; MCCARTY, B. Southern lawns: best management practices for the selection, establishment and maintenance of Southern lawngrasses. In: MCCARTY, B. (ed). Turfgrass establishment and management. Clemson University Public Service Publishing, vol.707, p.449-526, 2003.

SILVA, S.Á.C.G.; SANTOS, A.G.; SILVA, S.S.L.; LOGES, V.; SOUZA, F.H.D.; CASTRO, A.C.R. Characterization and selection of Brazilian native grasses for use as turfgrass. Acta Horticulturae, v.1215, p.255-258, 2018. DOI: http:// dx.doi.org/10.17660/ActaHortic.2018.1215.45
SOUZA, F.H.D; GUSMÃO, M.R.; MATTA, F.P.; CASTRO, A.C.R.; MITTELMANN, A.; FÁVERO, A.F.; JANK, L. Atributos desejáveis para gramados a serem cultivados sob condições brasileiras: uma proposta. Ornamental Horticulture, v.22, n.2, p.154-165, 2016. DOI: http://dx.doi.org/10.14295/oh.v22i2.841

YOUNGMAN, R.; KUHAR, T.; GYAWALY, S.; LAUB, C.; WU, S. Turfgrass insect management. Virginia Turfgrass Certification Manual, 2017. 4p. 